УДК $378.147: 349.6$

Панькевич Сергій Григорович

кандидат географічних наук, старший викладач кафедри екології Луцький національний технічний університет, м. Луцьк, Україна

eco-psg@ukr.net

\title{
ВИКОРИСТАННЯ ЖЕВ-РЕСУРСІВ У НАВЧАЛЬНОМУ КУРСІ «ЕКОЛОГІЧНЕ ПРАВО УКРАЇНИ»
}

\begin{abstract}
Анотація. Подано короткий огляд важливих для вивчення екологічного права спеціалізованих ресурсів Інтернету. Описано основні можливості та деякі нюанси роботи із сайтами правових баз даних, що надаються державними структурами і приватними організаціями. Акцентовано на можливостях розширеного пошуку на порталах Верховної Ради України, систем «Ліга-закон» та «НаУ-онлайн», у Сдиному державному реєстрі судових рішень. Наведено низку посилань на ресурси громадських організацій, що займаються природоохоронною діяльністю. Окреслено орієнтовну тематику й подано приклади формулювання конкретних практичних та індивідуальних занять, що спираються на використання тематичних веб-ресурсів. Оцінено методичне значення застосування інтернет-технологій для вивчення і викладання еколого-правових дисциплін.
\end{abstract}

Ключові слова: екологічне право; законодавство України; інтернет-ресурси; тематика практичних занять.

\section{1. ВСТУП}

Постановка проблеми. Навчальний курс з екологічного права $є$ однією з базових дисциплін у підготовці фахівців юридичного й екологічного профілів. У ньому розглядаються основні законодавчі документи і підзаконні акти, що регулюють загальні і спеціальні питання використання природних ресурсів й охорони довкілля; вивчаються існуючі екологічні стандарти і нормативи, аналізуються види екологічних правопорушень і правової відповідальності за них тощо.

Удосконалення методики викладання екологічного права і спецкурсів з екологоправових дисциплін визначено одним із приоритетних завдань державної політики (п. 34 Постанови ВРУ «Про Основні напрями державної політики України у галузі охорони довкілля, використання природних ресурсів та забезпечення екологічної безпеки») [8].

Варто зауважити, що у зв' язку з досить частим оновленням нормативної бази і все зростаючими обсягами прикладної еколого-правової інформації, вивчення цього предмету лише за підручниками не може бути повноцінним. Натомість уміле використання тематичних ресурсів Інтернету дозволяє значно підвищити ефективність як власне викладання дисципліни, так і засвоєння ії̈ студентами.

Аналіз досліджень і публікацій. Уведення курсу екологічного права у навчальні плани деяких природничих спеціальностей почало практикуватись в Україні ще на початку 1990-х років [6]. Із здобуттям незалежності почала активно розвиватись відповідна законодавча база, а разом із цим постійно вдосконалювався предмет i методи викладання екологічного права. До 1998 року було прийнято низку основоположних законів і кодексів, що регулювали правові аспекти охорони довкілля (закони «Про охорону навколишнього природного середовища», «Про охорону атмосферного повітря», «Про екологічну експертизу», Водний кодекс, Лісовий кодекс та ін.), після чого почали з'являтись спеціалізовані праці з екологічного права. Серед них - підручники і монографії Андрейцева В. I. (1996, 1997, 2001), Малишка М. I. 
(2001), Дмитренка I. А. (2001), Тищенка Г. В. (2001), Гетьмана А. П., Шульги М. В. $(2005,2009)$ та ін.

Дещо пізніше 3'явилася низка методичних посібників, покликаних підвищити ефективність вивчення екологічного права. Однак у більшості 3 них не прослідковується орієнтування на використання електронних джерел інформації. Наприклад, в одному 3 найновіших (2012) посібників $з$ екологічного права України, у списках рекомендованих джерел, наданих до кожної з тем, серед електронних ресурсів наявні лише посилання на окремі законодавчі акти на сайті Верховної Ради України [5]. Посилання на тематичні інтернет-ресурси частіше зустрічаються лише у спеціалізованих наукових працях, присвячених висвітленню конкретної екологоправової проблеми (як приклад - роботи Р. Марусенка [4], О. О. Сурілової [10] та ін.). Разом 3 тим власне методичні аспекти роботи 3 електронними ресурсами під час вивчення екологічного права висвітлені мало, що й спонукало автора до написання цієї статті.

Мета цієї публікації - висвітлити можливості і приклади використання відповідних інтернет-ресурсів у викладанні й вивченні екологічного права.

\section{2. РЕЗУЛЬТАТИ ДОСЛІДЖЕННЯ}

У сучасному інформаційному просторі існують десятки і сотні тематичних вебресурсів, грамотне використання яких може суттєво полегшити й оптимізувати процес вивчення екологічного права. Це і сторінки відповідних державних установ, електронні бібліотеки, сайти спеціалізованих правових систем, деяких громадських організацій, міжнародних природоохоронних організацій, і навіть сторінки регіональних засобів масової інформації. Далі спробуємо назвати й охарактеризувати деякі ресурси 3 названих категорій, які використовуємо у навчальному процесі.

Веб-ресурси як першоджерела правових документів. До цієї категорії відносимо офіційні сайти органів державної влади (у доменній зоні gov.uа), що приймають нормативні акти у сфері охорони довкілля. У першу чергу це, звичайно, база даних «Законодавство України» на сайті Верховної Ради України. Вона містить актуальні версії прийнятих законів, постанов, указів, законопроектів центральних органів влади. Хоча на головній сторінці $є$ застереження, що цей сайт має лише інформаційний характер (для офіційних посилань досі рекомендуються відповідні друковані видання), на ньому, як правило, представлені найновіші офіційні тексти законів і підзаконних актів. Серед переваг системи - наявність активних гіперпосилань на усі пов'язані документи, із вказуванням типу зв'язку («спричинив прийняття», «відсилає до», «змінюється пов' язаним документом», «вводиться в дію», «має відсилання з»). Також є можливість відслідковування усіх прийнятих змін і їх час (рис. 1), відображення статусу («чинний» чи «втратив чинність», із вказуванням законної підстави), пошук по тексту тощо. 


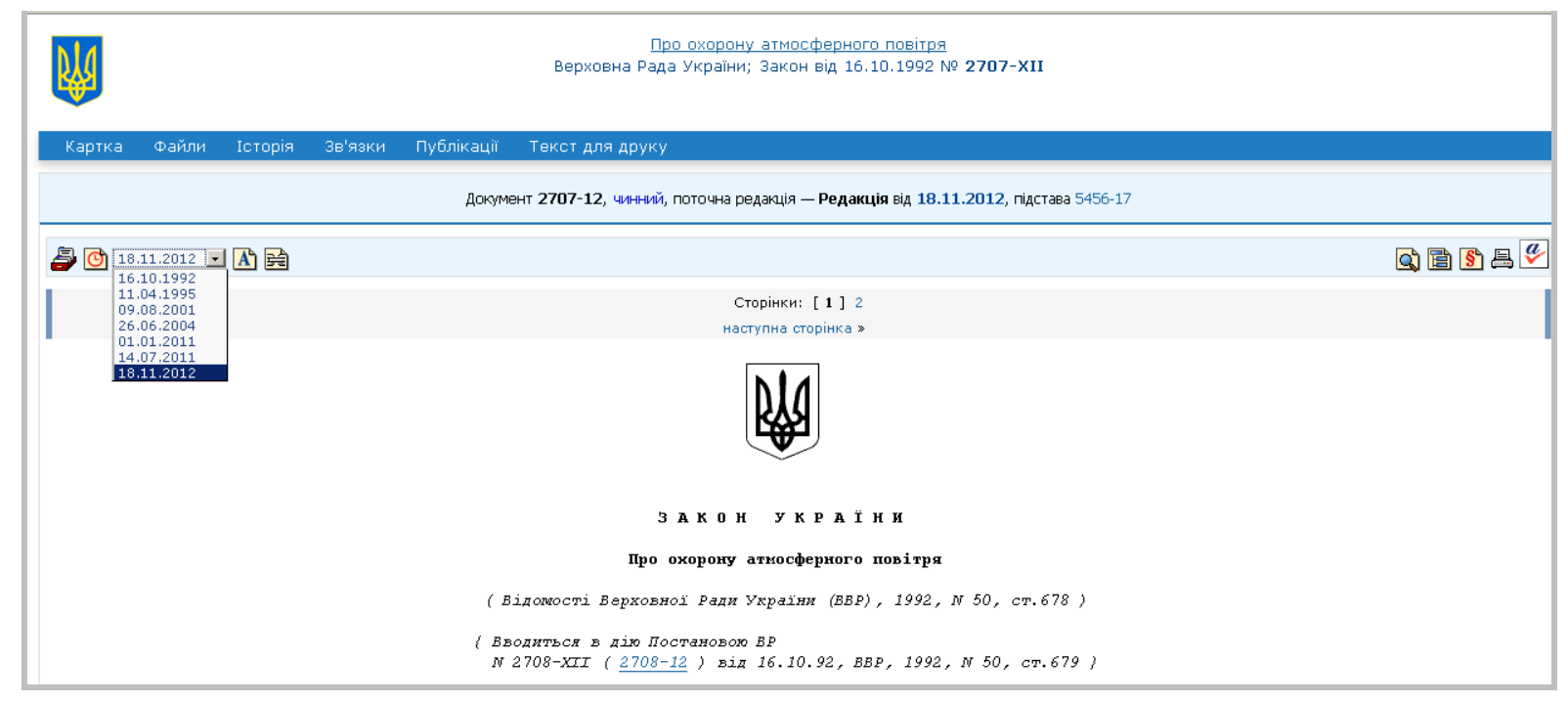

Рис. 1. Інтерфейс представлення законодавчих документів у базі даних «Законодавство Украӥни» на сайті Верховної Ради Украӥни. На верхній панелі стилізованих позначень можна перейти до короткої анотації документа, побачити час прийняття закону у різних редакціях і переглянути відповідні версії, подивитись пов'язані документи, здійснити пошук по тексту, вивести на друк чи зручно скопіювати у текстовий редактор

У цій системі наявний кількарівневий пошук (за назвою, по контексту, за датою прийняття, за типом документа, за видавником тощо). Виконуючи пошук за назвою, необхідно враховувати, що багато законодавчих документів у базі мають специфічне формулювання (наприклад, не «Санітарні норми і правила...», а «Про введення в дію санітарних норм і правил...»). Через ці та деякі інші особливості на практиці непоодинокі випадки, коли потрібний документ у базі не знаходиться. Для цього передбачено також розділ «Альтернативний пошук», де задіюються пошукові механізми популярних систем (найчастіше - Google).

Під час вивчення екологічного права одними 3 найзатребуваніших розділів ресурсу «Законодавство України» є відповідні розділи Кримінального кодексу України (ККУ) («Злочини проти довкілля», статті 236-254 [3]) і Кодексу України про адміністративні правопорушення (КУпАП) (Глава 7 - «Адміністративні правопорушення у сфері охорони природи, використання природних ресурсів, охорони культурної спадщини», статті 52-91 [1]). Це пов'язано з тим, що саме окремі статті цих розділів найчастіше зазнають змін, переважно в частині збільшення суми покарання за певний вид правопорушення (наприклад, штрафи за порушення правил рибальства у відповідній статті ККУ були збільшені у 2010 році, а в ст. 85 КУпАП — передбачені законопроектом від 14.08.2013 [7]). Очевидно, що в подібних випадках цінність інтернет-ресурсу є суттєво більшою, ніж у друкованих виданнях цих кодексів.

Ще одним офіційним джерелом еколого-правової інформації $\epsilon$ caŭm Міністерства екологї̈ та природних ресурсів Украӥни - www.menr.gov.иа, на якому в окрему категорію зібрані основні нормативні акти, що стосуються охорони довкілля. Водночас власні накази й постанови міністерства представлені текстами у хронологічному порядку на окремій сторінці — http://menr.gov.ua/content/category/291, а інші документи, що стосуються охорони довкілля (у т. ч. Укази Президента, Закони України і Постанови КМУ) подані у вигляді активних гіперпосилань на відповідні статті вже згадуваного порталу zakon.rada.gov.ua. У розділі «Міжнародне 
законодавство» на сайті Мінприроди представлені тексти (у формі доступних для скачування файлів формату .doc) деяких міжнародних конвенцій і угод, ратифікованих Україною. На жаль, чимало тематичних нормативних актів тут не представлені (про що й повідомляється фразою «Перелік не $\epsilon$ вичерпним та остаточним $i$ постійно змінюється з розвитком системи екологічного законодавства»), однак більшість найзатребуваніших документів наявні й досить зручно категоризовані. Попри це, на сайті описано можливість і реквізити для подання запиту на отримання публічної інформації, що стосується діяльності міністерства, а також є розділ із роз'ясненнями найчастіше запитуваних еколого-правових питань («Зв’язки 3 громадськістю» «Питання-відповідь»).

Важливими нормативними документами, що визначають тисячі кількісних критеріїв охорони довкілля і здоров'я населення, $\epsilon$ зведення Санітарних норм $\boldsymbol{i}$ правил. Це, зокрема, «Державні санітарні правила планування та забудови населених пунктів» (визначені, зокрема, нормативи санітарно-захисних зон навколо небезпечних об' єктів, допустимі рівні шуму, вібрації, електромагнітних полів у населених пунктах), "Державні санітарні правила охорони атмосферного повітря населених місиь (від забруднення хімічними та біологічними речовинами)» (у т. ч. наведено гранично допустимі концентрації у повітрі понад 500 хімічних речовин), «Основні санітарні правила забезпечення радіаційної безпеки Украӥни» та багато інших. Такі документи затверджуються у Міністерстві охорони здоров'я, хоча певний час деякі з них були відсутні на офіційному сайті www.moz.gov.ua, але знаходились на спеціалізованих порталах «Нормативно-директивні документи МО3 України» — http://mozdocs.kiev.ua і в комерційних правових базах даних. Однак на сьогоднішній день фактично усі діючі Санітарні норми і правила (у т. ч. й деякі, прийняті ще в СРСР) можна знайти і через пошук на сайті законодавства Верховної Ради України, і на сайті Державної санітарноепідеміологічної служби України [9], на яку є посилання на сайті МО3.

Утім, окрім ретельного вивчення правових першоджерел, не менш важливим $\epsilon$ вивчення практики їх застосування. Для таких цілей слугують науково-практичні коментарі, різноманітні юридичні консультації тощо.

Одним із необхідних електронних ресурсів, що дозволяє виконувати низку найрізноманітніших завдань аналізу правової інформації, $\epsilon$ база «Єоиний реєстр судових рішень», що доступний за адресою http://www.reyestr.court.gov.иa. У ній можна знайти рішення, ухвали і постанови судів усіх ланок, у тому числі за тематичними запитами. Це дає змогу порівняння процедури проходження і відмінностей у рішеннях різних судів за схожими справами, знаходження прецедентів вирішення різноманітних позовів і спорів. У базі цього сервісу десятки мільйонів документів, що стосуються рішень судів усіх інстанцій. Інтерфейс сайту дозволяє здійснювати пошук за регіоном розгляду, за формою судочинства, за категорією справи, за періодом надходження чи ухвалення рішення i т. д. Вибираючи категорії, можна обрати власне «природоохоронні» розділи - наприклад, серед адміністративних - «справи зі спорів 3 приводу охорони навколишнього середовища», серед яких, у свою чергу, виділяють підрозділи «забезпечення екологічної безпеки, у т. ч. при використанні природних ресурсів; екологічної безпеки поводження 3 відходами», «особливої охорони природних територій та об'єктів, визначених законом», та «спостереження, прогнозування та обліку в галузі довкілля, екологічної експертизи» (рис. 2). 
Єдиний державний реєстр судових рішень

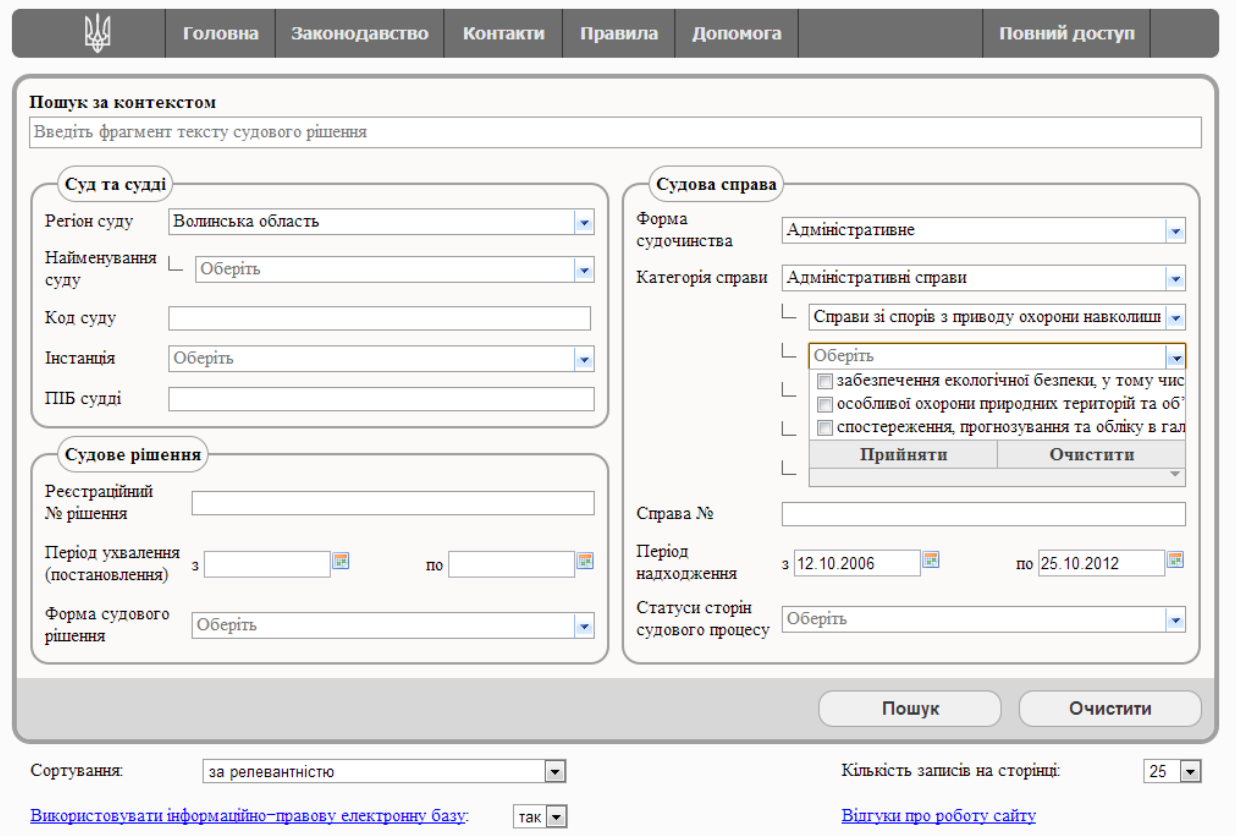

Рис. 2. Інтерфейс пошуку на сайті Єдиного державного реєстру судових рімень

Для знаходження інформації про рішення у сфері охорони природи, іноді доцільно вводити у пошук номери відповідних статей ККУ чи КУпАП, їхні назви, а також ключові фрази, що найчастіше зустрічаються у результуючих частинах судових постанов (наприклад, «правил рибальства», «природно-заповідного фонду», «знаряддя лову», «екологічної безпеки», «забруднюючих речовин», «шкоди довкіллю» і т. п.).

Крім офіційних порталів органів законодавчої, виконавчої та судової влади, заслуговують на увагу кілька інших потужних правових систем, реалізованих на базі сучасних інформаційних технологій. Це, зокрема, системи «Ліга-закон» та «НаУонлайн».

Система «Ліга-закон», представлена групою компаній «Ліга», зокрема інформаційною агенцією «ЛІГАБізнесІнформ», є професійною правовою базою даних, первинно призначеною для платного корпоративного використання на комп'ютерах користувачів (як в онлайновому, так i в офлайновому режимі). Схоже цільове призначення і у системи «Мега-НаУ» («НаУ» — «Нормативні акти України», надається ПрАТ «Інформтехнологія»), але дещо інші принципи технічної реалізації і наповнення.

В обох названих систем $\epsilon$ онлайнові ресурси, більшість матеріалів у яких надається у відкритому доступі. Правова база «Ліга-закон» представлена на сайті ligazakon.ua (вбудовано пошук від Google), онлайн-сервіси розміщені за адресою http://search.ligazakon.ua (є власний пошук). Важливою перевагою є наявність у базі (i, відповідно, у результатах пошуку) не лише нормативних актів, а й практичних коментарів і консультацій (у т. ч. з таких питань, як порядок нарахування і сплати екологічних зборів, розрахунок лімітів використання окремих видів природних ресурсів, процедури оскарження штрафів екологічних інспекцій і т. д.). Попри це, такого типу консультації можна отримати, задавши питання на ще одному ресурсі групи - тематичному юридичному форумі forum.liga.net.

Інтернет-відповідник системи «Мега-НаУ» називається «НаУ-онлайн» $\mathrm{i}$ знаходиться за адресою http://zakon.nau.иа. У ній є, окрім власне нормативних актів, 
окремі категорії нових надходжень з поділом на нові документи і зміни до існуючих, довідники термінів і стандартів, розділи судової практики, консультацій, документів місцевих органів влади (останні у платному доступі). У розділі «Класифікатор судових рішень» еколого-правова тематика відображається у категоріях «Адміністративні справи - Природні ресурси» й «Адміністративні правопорушення - Правопорушення в галузі охорони природи, використання природних ресурсів, охорони пам'яток історії та культури».

Ця система має розширений функціонал, що дозволяє зручно виконувати потрібний пошук. Після висвітлення результатів пошуку натискання на значок «Структура» дає змогу побачити класифікацію поданих документів (рис. 3), що значно полегшує відбір саме потрібної інформації.

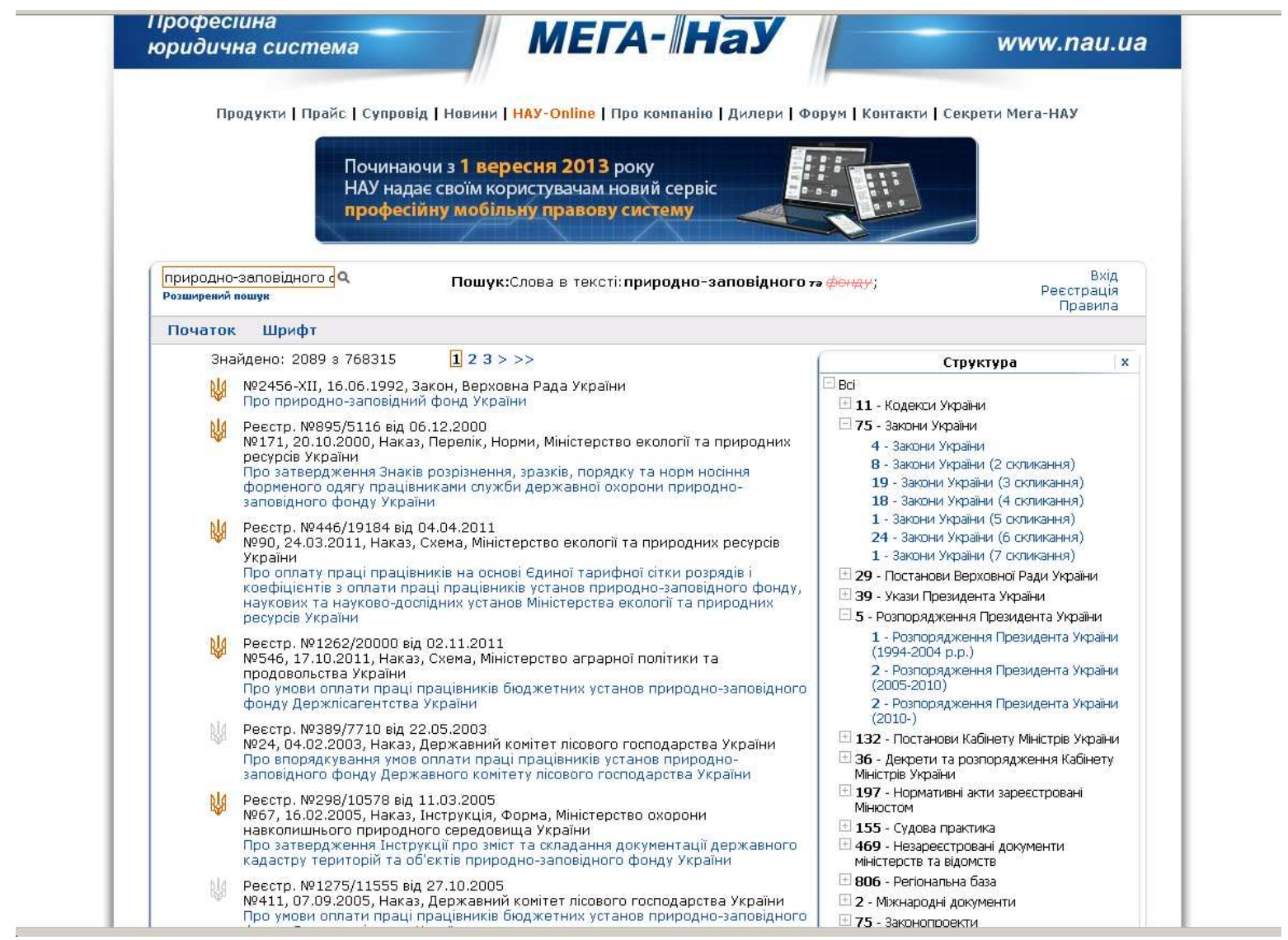

Рис. 3. Приклад видачі пошукової інформащії на сайті системи «НаУ-онлайн». На запит «природно-заповідного фонду» висвітлюється 2089 документів, але розкриття класифікатора (значок «Структура») дозволяє побачити і вибрати лише відповідну категорію - з кодексів, законів, постанов Верховної Ради (із вибором часу скликання), КМУ, із бази судової практики, із регіональних документів тощо

Також під час перегляду конкретного нормативного документа у пункті «зв’ язки» можна побачити як посилання 3 документа, так і на документ (така функція $є$ i на офіційному порталі Верховної Ради), а також, що особливо важливо - відповідну судову практику і статистику судових рішень, що спираються на даний нормативний акт.

Чимало освітніх і методичних матеріалів 3 екологічного права можна також знайти на спеціалізованих сторінках сайтів-електронних бібліотек. Як приклад можемо назвати розділ «Экологическое право» на сайті twirpx.com 
(twirpx.com/files/law/ecology), який містить понад 500 файлів еколого-правової тематики (від студентських рефератів до серйозних наукових монографій). Позитивним на цьому ресурсі $є$ й те, що власне автори можуть заблокувати скачування їхніх книг у разі порушення авторського права (як, наприклад, відбулось 3 підручниками «Екологічне право України» за ред. Гетьмана А. П., Шульги М. В.).

Одним із джерел наповнення українського сегменту Інтернету відомостями 3 практики застосування екологічного права $\epsilon$ сайти громадських організацій природоохоронного спрямування. Найпотужнішим ресурсом у цьому аспекті вважаємо сайт організації «Екологія. Право. Людина», яка видає однойменний журнал (до 2006 року називався «Вісник екологічної адвокатури»), і розміщує його заархівовані випуски у вільному доступі на спеціальній сторінці [2]. Окремі правові аспекти охорони природи висвітлюються також, зокрема, на сторінках сайтів ГО «За право громадян на екологічну безпеку» (ecopravo.org.ua), Національного екологічного центру України (necu.org.ua), ВЕГО «Мама-86» (mama-86.org.ua), Українського товариства охорони природи (ukrpryroda.org) та ін.

Повноцінний аналіз і вивчення багатьох еколого-правових питань передбачає комплексне використання описаних сервісів та інтернет-сторінок.

Приклади завдань. Використання вищезазначених інтернет-ресурсів дає змогу сформулювати і запропонувати до виконання студентами низки творчих завдань для практичної й індивідуальної роботи. Пропонуємо перелік деяких 3 них, апробованих у процесі викладання цієї дисципліни:

1) використовуючи Єдиний реєстр судових рішень, визначити:

- кількість зафіксованих порушень правил мисливства і рибальства в межах своєї області, району (вид правопорушення можна давати окремо - по варіантах);

- порівняти кількість виявлених порушень вказаного виду між адміністративними районами своєї області. Спробувати знайти пояснення максимальних і мінімальних показників (наявність об'єктів 3 режимом заповідання, концентрація і зайнятість населення, кількість екологічних інспекторів);

- діапазон суворості покарання за даним видом порушень: співвідношення кількості адміністративних i кримінальних проваджень, відсоток застосування мінімального i максимального штрафу, розміри відшкодування збитків, завданих природі. Виявити типові пом'якшуючі й обтяжуючі обставини, що найчастіше враховуються при винесенні відповідних рішень;

- проаналізувати випадки виправдальних рішень 3 екологічних правопорушень у своєму регіоні за останні 3-5 років;

2) використовуючи електронні правничі системи («Законодавство України» на сайті ВР, «НаУ-Онлайн» і т. п.):

- виписати хронологію змін до основоположних законів у сфері охорони довкілля (за варіантами );

- виписати час і зміст внесених змін до окремих статей ККУ і КУПАП, що стосуються екологічного права. Вказати зміну розміру штрафів. За реєстром судових рішень виявити динаміку скоюваних правопорушень до і після внесених змін;

- аналізуючи відповідні Санітарні правила і норми, виявити речовиниполютанти, для яких було змінено первинно встановлене значення ГДК (як приклад - збільшення ГДК діоксиду азоту в атмосферному повітрі). Обгрунтувати можливі причини і правові наслідки таких змін; 
- проаналізувати відмінності в існуючих екологічних нормативах України, Росії, Білорусі, Республіки Польщі, США (доцільно одному студенту видавати для порівняння лише якийсь один із видів нормативів, наприклад, допустимі рівні електромагнітного випромінювання для населених місць, допустимий вміст нітратів у водах рибогосподарського призначення тощо);

- виписати хронологію і порівняти час імплементації основних міжнародних угод у сфері охорони довкілля, підписаних Україною.

\section{3. ВИСНОВКИ ТА ПЕРСПЕКТИВИ ПОДАЛЬШИХ ДОСЛІДЖЕНЬ}

Широке використання спеціалізованих інтернет-сервісів і ресурсів, присвячених екологічному законодавству, дозволяє значно розширити коло вирішуваних завдань під час вивчення екологічного права. Наразі студенти закріплюють навички роботи із сучасними інформаційними системами, розвивають уміння пошуку найактуальніших змін у нормативних актах природоохоронного характеру, набувають досвіду роботи з правовими базами даних.

Попри це, робота з електронними ресурсами судової статистики (у т. ч. виконання завдань на вибірку i порівняння статистики судових рішень 3 певного виду екологічного правопорушення) дає повноцінне уявлення про практику застосування конкретних правових норм, відмінності у їх трактуванні, видах покарання тощо. Такі навички $€$ дуже важливими як для спеціалістів юридичного профілю, так i для випускників екологічних спеціальностей, що працюватимуть екологічними інспекторами чи спеціалістами регіональних управлінь охорони навколишнього середовища.

У цій статті окреслено лише певні види й подано приклади завдань, що передбачають використання спеціалізованих веб-ресурсів у вивченні екологічного права. Взагалі ж застосування інтернет-технологій дає можливість суттєво розширити тематику, зміст та методи практичних й індивідуальних занять з цієї дисципліни. Тому перспективними вважаємо подальші розробки конкретних методичних прийомів 3 використання IКТ для навчання і контролю знань студентів 3 екологічного права. Доцільним також було б створення спеціалізованого освітнього інтернет-ресурсу, який би поєднав законодавчу вибірку з цієї тематики з науково-практичними коментарями, практикою застосування (за видами порушень і в регіональному аспекті), методикою викладання тощо.

\section{СПИСОК ВИКОРИСТАНИХ ДЖЕРЕЛ}

1. Адміністративні правопорушення у сфері охорони природи, використання природних ресурсів, охорони культурної спадщини / Глава 7 Кодексу України про адміністративні правопорушення [Електронний ресурс]. - Режим доступу : http://zakon4.rada.gov.ua/laws/show/8073110/paran313\#n313.

2. Екологія. Право. Людина (Вісник екологічної адвокатури) [Електронний ресурс]. — Режим доступу : http://epl.org.ua/zhurnal-ekologija-pravo-ljudina/.

3. Злочини проти довкілля / Розділ VIII Кримінального Кодексу України [Електронний ресурс]. Режим доступу : http://zakon4.rada.gov.ua/laws/show/2341-14/page7.

4. Марусенко Р. І. Деякі проблеми правового режиму свердловин на воду / Р. І. Марусенко // Вісник Вищої ради юстиції. - 2012. — № 4 (12). - С. 64-77.

5. Навчально-методичний посібник для практичних занять та самостійної роботи 3 навчальної дисципліни «Екологічне право України» для студентів денної форми навчання / [уклад. : А. П. Гетьман, С. В. Размєтаєв, Г. В. Анісімова та ін.]. - Х. : Нац. ун-т «Юрид. Акад. України ім. Ярослава Мудрого», 2012. - 96 с. 
6. Погрібний О. О. Становлення галузі екологічного права в Україні / О. О. Погрібний // Ученые записки Таврического нац. ун-та им. В. И. Вернадского. Серия «Юридические науки». - Т 19 (58). -2006. — № 3. - С. 122-125.

7. Проект Закону про внесення змін до Кодексу України про адміністративні правопорушення щодо посилення відповідальності за порушення правил рибальства [Електронний ресурс]. — Режим доступу : http://w1.c1.rada.gov.ua/ pls/zweb2/webproc4_1?pf3511=48026.

8. Про Основні напрями державної політики України у галузі охорони довкілля, використання природних ресурсів та забезпечення екологічної безпеки / Постанова Верховної Ради України // Відомості Верховної Ради України. - 1998. - № 38-39. - Ст. 248.

9. Санітарні правила і норми на сайті Державної санітарно-епідеміологічної служби України [Електронний ресурс]. - Режим доступу : http://www.dsesu.gov.ua/wses/dsesu.nsf/ prBRc?OpenView\&ID=UA.

10. Сурілова О. О. Порівняльне екологічне право : навчальний посібник / О. О. Сурілова. — Одеса : Феникс, 2010. - 220 с.

Матеріал надійшов до редакиї 16.10 .2013 p.

\title{
ИСПОЛЬЗОВАНИЕ ШЕВ-РЕСУРСОВ В УЧЕБНОМ КУРСЕ «ЭКОЛОГИЧЕСКОЕ ПРАВО УКРАИНЫ»
}

\section{Панькевич Сергей Григорьевич}

кандидат географических наук, старший преподаватель кафедры экологии Луцкий национальный технический университет, г. Луцк, Украина eco-psg@ukr.net

\begin{abstract}
Аннотация. Представлен краткий обзор важных для изучения экологического права специализированных ресурсов интернета. Описаны основные возможности и некоторые нюансы работы с сайтами правовых баз данных, предоставляемых государственными структурами и частными организациями. Акцентируется на возможностях расширенного поиска на порталах Верховной Рады Украины, систем «Лига-закон» и «НаУ-онлайн», в Едином государственном реестре судебных решений. Приведен ряд ссылок на ресурсы общественных организаций, занимающихся природоохранной деятельностью. Определена ориентировочная тематика и представлены примеры формулировки конкретных практических и индивидуальных занятий, опирающихся на использование тематических веб-ресурсов. Оценено методическое значение применения интернет - технологий при изучении и преподавании эколого-правовых дисциплин.
\end{abstract}

Ключевые слова: экологическое право; законодательство Украины; интернет-ресурсы; тематика практических занятий.

\section{USE OF WEB-RESOURCES IN THE EDUCATIONAL COURSE "ENVIRONMENTAL LAW OF UKRAINE"}

\section{Serhiy H. Pankevych}

$\mathrm{PhD}$ (geographical sciences), lecturer of the Department of ecology

Lutsk National Technical University, Lutsk, Ukraine

eco-psg@ukr.net

\begin{abstract}
The review of the important ecological-law web-resources is submitted. The main possibilities and some nuances of work with sites of legal databases are described. It is accented on opportunities of expanded search on portals of the Verkhovna Rada of Ukraine, «Liga-Zakon» and «NAU-online» systems, in the Unified State Register of judgments. Some references on resources of the public organizations which are engaged in nature protection activities are given. The approximate subject is defined and examples of the concrete practical and individual training, based on the use of thematic web resources, are presented. Methodical value of application the Internet-technologies when studying and teaching ekological-law disciplines is estimated.
\end{abstract}


Keywords: ecological law; legislation of Ukraine; Internet resources; subject of a practical training.

\section{REFERENCES (TRANSLATED AND TRANSLITERATED)}

1. Administrative offenses in the field of environmental protection, use of natural resources, protection of a cultural heritage [online] / Chapter 7 of the Code of Ukraine on Administrative Offences. - Available from : http://zakon4.rada.gov.ua/laws/show/80731-10/paran313\#n313 (in Ukrainian).

2. Ekologija. Pravo. Ljudina (Bulletin of Environmental Advocacy) [online]. - Available from : http://epl.org.ua/zhurnal-ekologija-pravo-ljudina/. (in Ukrainian).

3. Enviromental offences [online] / Chapter VIII of the Criminal Code of Ukraine. - Available from : http://zakon4.rada.gov.ua/laws/show/2341-14/page7 (in Ukrainian).

4. Marusenko R. I. Some problems of legal regimes of the water wells / R. I. Marusenko // «Visnyk Vishhoji rady justicii» \# 4 (12), 2012. - S. 64-77. (in Ukrainian).

5. Ekological law of Ukraine. Manual for practical classes and individual work for students / uklad.: A. P. Get'man, S. V. Razmetaev, G. V. Anisimova. - Kharkiv. : Nac. un-t «Jurid. Akad. Ukrajiny im. Jaroslava Mudrogo», 2012. — 96 S. (in Ukrainian).

6. Pogribnij O. O. The formation of area of environmental law in Ukraine / O. O. Pogribnij // Uchenye zapiski Tavricheskogo nac. un-ta im. V. I. Vernadskogo. Serija «Juridicheskie nauki». T 19 (58) \#3, 2006. - S.122-125. (in Ukrainian).

7. The Draft Law on amending to the Code of Ukraine on Administrative Offences to strengthen accountability for violation of the fisheries regimes. [online]. - Available from: http://w1.c1.rada.gov.ua/ pls/zweb2/webproc4_1?pf3511=48026. (in Ukrainian).

8. The Principles of State Policy of Ukraine on Environmental Protection, Natural Resources and Ecological Safety / Resolution of Verkhovna Rada of Ukraine // Vidomosti Verhovnoji Rady Ukrainy, 1998, N 3839, st.248. (in Ukrainian).

9. Sanitary Regulations \& Norms on site of the State Sanitary and Epidemiological Departament of Ukraine. [online]. - Available from : http://www.dsesu.gov.ua/wses/dsesu.nsf/ prBRc?OpenView\&ID=UA.

10. Surilova O. O. Comparative environmental law / O. O. Surilova. — Odesa : Feniks, 2010. — 220 s. (in Ukrainian). 